\title{
MEROKOK DALAM PERSPEKTIF MUHAMMADIYAH DAN NAHDHATUL ULAMA
}

\author{
Oleh : Muhammad Ihsan'1
}

\begin{abstract}
Abstrak
Smoking is an activity that has become part of human life in differene parts of the world. However smoking is a thing that can be said to be relatively new, because cigarettes have not been known at the time of Prophet SAW. Because it is a new one, it's not suprising it is appears a variety of different opinions in a non legislation, both ulama in person or religious organization which is often used as a reference for the general public. Muhammadiyah throught the council of tarjih have established to consider unlawful the smoking, while Nahdatul Ulama established that the smoking law merely improper. The differences of opinion certainly is something to be examined futher. Moreover, both organization are the largest organization in Indonesia and has fanaticism its self. So that whatever be the decicion would have passable
\end{abstract}

Kata Kunci: Merokok, Muhammadiyah, NU

\section{A. Pendahuluan}

Diakui atau tidak rokok sudah merupakan bagian yang sudah tidak dapat dipisahkan lagi dalam peradaban manusia. Rokok merupakan rajangan halus daun tembakau yang dibalut dengan menggunakan kertas tipis serta dilekatkan dengan perekat. Bagi sebagian orang, rokok sudah menjadi semacam kebutuhan primer yang harus dipenuhi. Bahkan muncul statemen yang mengatakan dari pada tidak merokok, lebih baik tidak makan. Fenomena semacam ini tentu merupakan salah satu bentuk pergeseran rokok dalam kehidupan manusia yang pada awalnya hanya merupakan kebutuhan sekunder sekarang berubah menjadi kebutuhan primer.

Masyarakat mengakui bahwa industri rokok telah memberikan manfaat ekonomi dan sosial yang cukup besar. Industri rokok juga telah memberikan

1 Penulis adalah salah satu salah satu dosen luar biasa pada Fakultas Syariah IAIN Langas. E-mail: muhammad.ihsan28@gmail.com

Vol. 4 No. 1 Tahun 2017 
pendapatan yang cukup besar bagi negara ${ }^{2}$. Bahkan, tembakau sebagai bahan baku rokok telah menjadi tumpuan ekonomi bagi sebagian petani. Namun di sisi lain, merokok dapat membehayakan kesehatan (dlarar), dan berpotensi terjadinya pemborosan (isrâf), dan merupakan tindakan tabdzir. Secara ekonomi penananggulangan bahaya rokok juga cukup besar. Menurut ahli kesehatan, rokok mengandung nikotin dan zat lain yang membahayakan kesehatan ${ }^{3}$.

Disamping kepada perokok, tindakan merokok dapat membahayakan orang lain, khususnya yang berada di sekitar perokok. Hukum merokok tidak disebutkan secara tegas oleh Al-Quran dan Sunnah. Oleh karena itu fuqaha mencari solusinya melalui ijtihad. Sebagaimana layaknya masalah yang hukumnya digali lewat ijtihad, hukum merokok diperselisihkan oleh fuqaha 4 .

Agamawan sebagai moral and social control pastinya mesti turun dalam pergulatan perbincangan ini memberi solusi terhadap problem sosial yang muncul. Di Indonesia sendiri kalangan agamawan diantaranya diwakili oleh dua ormas besar Nahdatul Ulama dan Muhammadiyah. Muhammadiyah berfatwa bahwa rokok ditengarai sebagai produk berbahaya dan beradiktif serta mengandung 4000 zat kimia, diantara zat kimia tersebut berdasarkan penelitian terbaru, menyebutkan bahwa terdapat 200-an racun yang berbahaya dalam sebatang rokok. Sementara itu Badan Kesehatan Dunia/ WHO menyebutkan bahwa di Amerika, sekitar 346 ribu orang meninggal tiap tahun dikarenakan rokok. Dan tidak kurang dari 90\% dari 660 orang yang terkena penyakit kanker di salah satu rumah sakit Sanghai Cina adalah disebabkan rokok. Juga terdapat penelitian yang menyebutkan bahwa 20 batang rokok per-hari akan menyebabkan berkurangnya 15\% hemoglobin,

2 Aliansi Masyarakat Tembakau Indonesia, "Cukai Rokok Penyumbang Terbesar Penerimaan Negara”, dalam http://amti.id/cukai-rokok-penyumbang-terbesar-penerimaan-negara (06-oktober 2016)

${ }^{3}$ Halo sehat, "74 Bahaya Merokok Bagi Kesehatan Tubuh Yang Mematikan” dalam http://halosehat.com/gaya-hidup/gaya-hidup-buruk/74-bahaya-merokok-bagi-kesehatan-tubuhyang-mematikan (12 Maret 2016)

${ }^{4}$ Tim Lembaga Fatwa MUI Himpunan Fatwa MUI Sejak 1975. Jakarta 2002 h. 196. 
yakni zat asasi pembentuk darah merah. Racun utama pada rokok adalah tar, nikotin dan karbon monoksida ${ }^{5}$

Tar sendiri adalah substansi hidrokarbon yang bersifat lengket dan menempel pada paru-paru. Sementara nikotin adalah zat adiktif yang mempengaruhi syaraf dan peredaran darah. Zat ini bersifat karsinogen dan mampu memicu kanker paru-paru yang mematikan. Karbon monoksida adalah zat yang mengikat hemoglobin dalam darah, membuat darah tidak mampu mengikat oksigen. Efek racun pada rokok ini membuat pengisap asap rokok mengalami resiko14 kali lebih besar terkena kanker paru-paru, mulut, dan tenggorokan dari pada mereka yang tidak menghisapnya. Penghisap rokok, berdasarkan penelitian, juga punya kemungkinan 4 kali lebih besar untuk terkena kanker esophagus dari mereka yang tidak menghisapnya ${ }^{6}$.

Namun demikian rokok sendiri adalah komoditas yang laris. Sangat jarang toko atau warung yang tidak menjual rokok. Bahkan beberapa pemilik toko besar atau kecil pernah mengungkapkan rokok bisa mengisi $40 \%$ sampai 50\% barang terlaris yang terjual setiap harinya. Kenyataan semacam ini tentu merupakan sebuah fakta yang sangat fantastis, belum lagi perusahaan-perusahaan besar yang memproduksi rokok, tentu akan mendatangkan keuntungan yang bisa dikatakan besar juga. Sudah banyak sekali berbagai publikasi yang membicarakan tentang bahaya dan bagaimana hukum dari mengkonsumsi rokok ${ }^{7}$.

Ulama' nusantara juga tidak pernah lepas untuk memberikan hukum tentang rokok, baik secara pribadi maupun organisasi ${ }^{8}$. Sebagai komoditas nomor wahid, bisa dikatakan rokok memiliki daya tarik yang sangat banyak sekali. Padahal rokok ibarat senjata bermata dua sebagai senjata ekonomi sekaligus sebagai senjata pembunuh yang sangat ampuh. Banyak sekali fakta yang

5 Lihat Yusuf Amin Nugroho, "Fikih Al-Ikhtilaf 2012" dalam http:// semuaguru.blogspot.com/2011/06/fiqh-khilafiyah-nu-muhammadiyah-seputar.html

${ }^{6}$ Umi Istiqomah, Upaya Menuju Generasi Tanpa Merokok Pendekatan Analisis Untuk Menangulangi Dan Mengantisipasi Remaja Merokok. Surakarta 2003 hal. 20

7 Abu Umar Basyir, Mengapa Ragu Untuk Tinggalkan Rokok, (Jakarta : Pustaka AtTazkia, 2006) hal.1-2

8 Diantara yang menulis tentang rokok adalah Syeikh Ihsan Jampes dalam karyanya Irsyadul Ikhwan, Li bayani Syurbil Qahwah wa Dukhan. Kitab Kopi dan Rokok ( Pustaka Pesantren : Yogyakarta,2009)

Vol. 4 No. 1 Tahun 2017 
menegaskan semacam itu, bahwa rokok memiliki daya ekonomi yang besar. Namun tidak sedikit pula orang yang strees atau bahkan sampai meninggal dunia disebabkan karena mengkonsumsi rokok. Kenyataan semacam inilah yang kemudian menjadi persoalan pelik dan besar untuk bagaumana memberikan solusi atas hukum yang pasti dan tidak menguntungkan sebagian orang.

Berbagai kajian ilmu kedokteran mengatakan bahwa sebenarnya rokok merupakan salah satu hal yang dapat membahayakan kesehatan tubuh manusia. Rokok juga oleh sebagian orang dikatakan sebagai perbuatan yang sia-sia (mubadzir) dan sebuah pemborosan, karena bisa membuat orang menjadi kecanduan. Sebagian yang lain bahkan mengatakan bahwa, merokok dapat memabukkan dan melemahkan tubuh, serta masih banyak lagi dampak buruk yang dihasilkan dari merokok

Sebagai barang yang ditemukan belakang ini bukan pada zaman Rasulallah, sudah tentu para ulama'berijtihad untuk menghukumi benda tersebut. Karena memang pada kenyataanya tidak ada satu nass pun baik dalam Al-Qur'an maupun hadist yang secara ekplisit memberikan kejelasan tentang bagaimana hukum rokok. Namun yang namanya ijtihad tentu bisa menghasilkan sebuah perbedaan di dalam keputusan yang dihasilkan.

Perbedaan pendapat di antara para ahli fikih mengenai hukum rokok tentu tidak dapat dihindari dan selalu berakhir dengan kontroversi yang tidak pernah selesai. Ini merupakan konsekuensi yang harus diperoleh dalam sebuah diskusi oarang banyak untuk menentukan dan mengambil sebuah hukum. Meskipun keragaman pendapat berupa fatwa mengenai hukum rokok selama ini sudah banyak terbukukan, namun tetap saja masih terdapat kontraversi yang tidak pernah ada akhirnya

Hingga sampai detik ini, memang dalam kenyataannya para ulama' berbeda pendapat dalam memberikan hukum rokok. Meskipun sudah sejak awal abad XI Hijriyah atau sekitar empat ratus tahun yang lalu, rokok sudah dikenal dan membudaya di berbagai belahan dunia Islam, namun keberadaannya tetap menjadi kontoversi. Sejak itulah sampai sekarang hukum rokok gencar dibahas oleh para ulama di berbagai negeri, baik secara kolektif maupun pribadi. Untuk 
masalah rokok ini secara sederhana dapat digolongkan seperti halnya makanan dan minuman yang pada dasarnya mubah, sebab tidak ada satupun nass yang secara jelas dan tegas melarangnya. Akan tetapi dalam menetapkan hukum suatu masalah dapat ditetapkan atas dasar manfaa't dan madharatnya. Apapun yang ada manfaatnya dan juga ada kemudharatan dalam suatu masalah yang ditetapkan hukumnya, maka dicari mana yang lebih membawa maslahah.

Perbedaan pendapat di antara para ulama' mengenai hukum rokok memang merupakan sesuatu yang biasa dan tidak dapat dihindari dan berakhir kontroversi. Itulah keragaman pendapat yang merupakan fatwa-fatwa yang selama ini telah banyak terbukukan. Ada beberapa pendapat yang dikeluarkan dalam memberikan hukum tentang rokok. Pertama, pendapat yang mengharamkan Kedua, pendapat yang makruh Ketiga, pendapat yang mubah Keempat, sikap yang berada di tengah-tengah, tidak mengeluarkan pendapat apapun, dan Kelima, pendapat rokok bisa terkena masing-masing hukum tersebut, (bisa haram, makruh, dan mubah) sesuai dengan situasi dan kondisi. ${ }^{9}$

Masing-masing dari berbagai pendapat yang dikeluarkan oleh para ulama' tersebut memiliki dalil masing-masing yang menguatkan pendapatnya tersebut. Hingga tidak mengherankan kemudian berbagai argumen tersebut kemudian menimbulkan pro dan kontra dalam menanggapinya. Berbagai kontroversi hukum yang terjadi tersebut terjadi karena nash yang menjadi patokan hukumnya bersifat umum, yakni larangan melakukan segala sesuatu yang dapat membawa kerusakan, kemudharatan atau kemafsadatan. Namun jika melihat geliat dan antusiame serta berbagai pertimbangan yang sekarang ini sudah nampak di permukaan, maka banyak juga yang mengatakan bahwa rokok justru menjadi seuatu yang bisa membuat tentram dan tenang fikiran.

Menurut beberapa ulama berpendapat bahwa hukum rokok tergantung pada orang yang sedang melakukannya. Jika sudah banyak mudharatnya dan membahayakan tubuh maka jelas haram hukumnya, namun jika masih belum

9 Mashur Hasan Salman dan Abdullah bin Abdu al-Hamid Al Asari, Rokok sang Pembunuh Berdarah Dingin, Alih Bahasa Abu Umar baasyir Al Maidani (Sukaharjo : Darul Iman, 2003) hlm. 83 
terlihat maka hanya bisa dihukumi makruh dan tentu saja harus dijauhi karena dikhawatikan akan berdampak negatif bagi masa depannya.

Namun berbeda dengan pendapat yang dikeluarkan oleh Muhammadiyah yang mengatakan bahwa memang meskipun rokok hukumnya tidak dijelaskan secara rinci dalam al-qur'an atau hadist, jika melihat dari berbagai aspek yang ada di dalamnya serta berbagaipertimbangan maka rokok itu hukumnya haram. Sebab dibandingkan dengan manfaatnya, rokok lebih banyak mudharat yang didatangkan dalam kehidupan.

Berbeda lagi dengan keputusan yang dikeluarkan oleh Nahdlatul Ulama' (NU). Meskipun kedua lembaga ini bisa dikatakan memilki gen ideologi yang hampir sama, namun dalam mengeluarkan hukum rokok tidaklah sama. NU menganggap hukum rokok cukup hanya sebatas makruh saja dan tidak sampai haram. Hal ini dikarenakan karena memang baik di dalam al-Qur'an maupun Hadis yang mengharamkan dan membahas tentang masalah rokok. Selain tentunya tidak dapat dipungkiri bahwa bagi sebagain orang rokok menjadi semacam teman dalam hidupnya dan banyak memberikan inspirasi dalam kehidupannya, selain tentunya dengan berbagai pertimbangan yang akurat sesuai dengan syariat Islam.

Perbedaan pendapat yang terjadi antara kedua organiasi terbesar di Indonesia ini tentunya sangat menarik sekali untuk dikaji secara lebih mendalam dan secara lebih terperinci lagi. Sebab sebagai organiasi yang memiliki jumlah masa terbanyak di Indonesia. Tentu akan berdampak pula pada para pengikut fanatiknya yang sudah menjadi bagian dari organiasai ini. Karena memang tidak bisa dipungkiri jika kedua organiasi ini mengeluarkan suatu pendapat, maka pendapat itu akan dijadikan sebagai rujukan oleh warganya. Sehingga jika dikatakan haram maka pengikutnya akan mengikutinya, begitu pula sebaliknya. Dengan begitu maka akan terjadi perbedaan pendapat yang cukup kuat. Selain itu karena ditengah perbedaan pendapat para ulama' tentang hukum rokok, tidak sedikit dari kalangan umat muslimin yang sudah mengetahui dampak negatif dari rokok baik dalam kesehatan maupun perekonomian masih tetap saja merokok dengan menggunakan berbagai alasan yang sulit untuk dibantah. 


\section{B. Fatwa Muhammadiyah Tentang Hukum Rokok}

Fatwa berasal dari kata fataay, fatwa merupakan sebuah isim (kata benda) yang digunakan dengan makna al-iftaa'. Dalam kitab Mafaahim Islamiyyah diterangkan bahwa secara literal, kata al-fatwa bermakna jawaban atas persoalanpersoalan syari'at atau perundang-undangan yang sulit. Sedangkan al-iftaa' adalah penjelasan hukum-hukum dalam persoalan-persoalan syari'at, undangundang dan semua hal yang berkaitan dengan pertanyaan-pertanyaan orang yang bertanya. ${ }^{10}$

Sedangkan fatwa menurut arti syari'at ialah suatu penjelasan hukum syar'iyah dalam menjawab suatu perkara yang diajukan oleh seseorang yang bertanya, baik penjelasan itu jelas/terang atau tidak jelas (ragu-ragu) dan penjelasan itu mengarah pada dua kepentingan yakni kepentingan pribadi atau kepentingan masyarakat banyak. ${ }^{11}$

Muhammadiyah memberikan fatwa haram merokok melalui keputusan Majelis Tarjih dan Tajdid Pimpinan Pusat Muhammadiyah. No.6/SM/MTT/III/2010. Dengan menggunakan beberapa alasan yang berlandaskan pada dalil-dalil al-Quran dan Sunnah ${ }^{12}$. Dalil yang berasal dari alQuran antara lain Surat al-A'raf ayat 157, al-Baqarah ayat 195, an-Nisa' ayat 29, al-Isra' ayat 26-27. Adapun hadis yang digunakan sebagai dalil pengharaman rokok adalah hadis dari Ibnu Majah, Ahmad, dan Malik, serta hadis dari Ahmad dan Abu Daud.

Metode yang digunakan adalah bayani, ta'lili dan Istislahi. Bayani (semantik) yaitu metode yang menggunakan pendekatan kebahasaan. Ta'lili (rasionalistik) yaitu metode penetapan hukum yang menggunakan pendekatan penalaran. Istislahi (filosofis) yaitu metode penetapan hukum yang menggunakan pendekatan kemaslahatan. ${ }^{13}$

${ }^{10}$ Mardani, Ushul Fiqh,(Jakarta: Raja Wali Press, 2013), hlm. 373-374.

11 Rohadi Abd Fattah, Analisa Fatwa Keagaman dalam Fiqh Islam, (Jakarta: Bumi Aksara, 1991), hlm. 7.

12 Fatwa Majelis Tarjih dan Tajdid Pimpinan Pusat Muhammadiyah. No.6/SM/MTT/III/2010. Tentang Hukum Merokok

13 Asjmuni Abdurrahman, Manhaj Tarjih Muhammadiyah: Metodologi dan Aplikasi, Cetakan III, (Yogyakarta: Pustaka Pelajar, 2004), hlm. 103. 
Sedangkan pendekatan yang digunakan dalam menetapkan hukum-hukum ijtihadiah adalah: Al-Tafsir al-ijtima'i al-ma'asir (hermeneutik); Al-Tarikhiyyah (historis); Al-Susiulujiyah (sosiologis); Al-Antrufulujiyah (antropologis). Adapun teknik yang digunakan dalam menetapkan hukum adalah Ijmak, Qiyas, Mashalih Mursalah, serta 'Urf. ${ }^{14}$

Lebih jelasnya, Majelis Tarjih Muhammadiyah mengemukakan dua dalil utama dalam pengharaman rokok, yaitu al-muqaddimât an-naqliyah (penegasan premis-premis syariah), yang terdiri dari beberapa alasan. ${ }^{15}$

1. Al-muqaddimât an-naqliyah (penegasan premis-premis syariah)

a. Agama Islam (syariah) menghalalkan segala yang baik dan mengharamkan khabâits (segala yang buruk), sebagaimana di tegaskan dalam al-Quran:

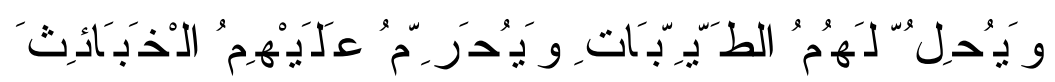

Artinya: ....Dan menghalalkan bagi mereka segala yang baik dan mengharamkan bagi mereka segala yang buruk.... (QS. Al-A'raf/ 7: 157).

b. Agama Islam (syariah) melarang menjatuhkan diri ke dalam kebinasaan dan perbuatan bunuh diri sebagaimana dinyatakan dalam al-Quran:
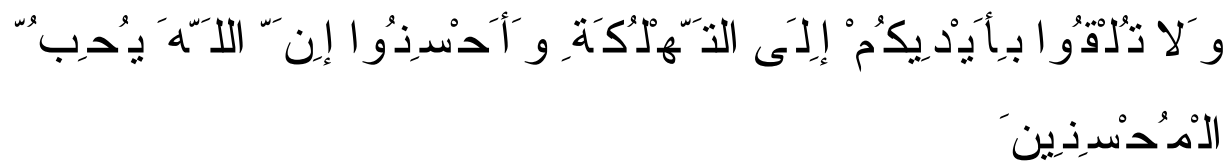

Artinya: ...Dan janganlah kamu menjatuhkan dirimu sendiri ke dalam kebinasaan, dan berbuat baiklah, Karena Sesungguhnya Allah menyukai orang-orang yang berbuat baik. (QS. Al-Baqarah/2: 195) 177.

${ }^{14}$ Jaih Mubarok, Metodologi Ijtihad Hukum Islam, (Yogyakarta: UII Press, 2002), hlm.

15 Fathurrahman Djamil, Metode Ijtihad Majlis Tarjih Muhammadiyah, Cet. Ke-1 (Jakarta: Logos, 1995), hlm. 87. 


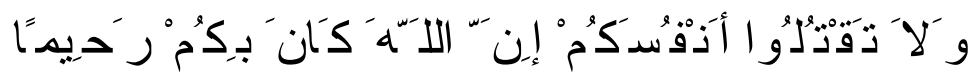

Artinya: Dan janganlah kamu membunuh dirimu; Sesungguhnya Allah adalah Maha Penyayang kepadamu.(QS. An-Nisa'/4: 29)

c. Larangan perbuatan mubazir dalam al-Quran:

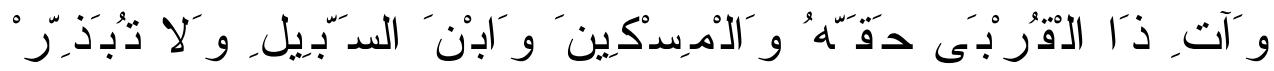

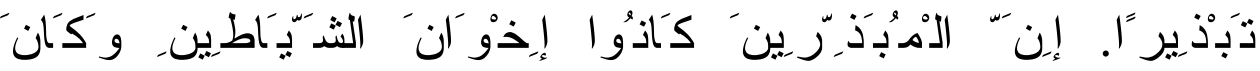

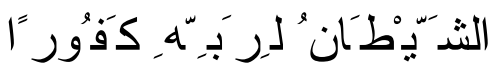

Artinya: Dan berikanlah kepada keluarga-keluarga yang dekat akan haknya, kepada orang miskin dan orang yang dalam perjalanan dan janganlah kamu menghambur-hamburkan (hartamu) secara boros.Sesungguhnya pemboros-pemboros itu adalah Saudara-saudara syaitan dan syaitan itu adalah sangat ingkar kepada Tuhannya. (QS. AlIsra'/ 17: 26-27).

d. Larangan menimbulkan mudarat atau bahaya pada diri sendiri dan pada orang lain dalam hadis riwayat Ibnu Majah, Ahmad, dan Malik:

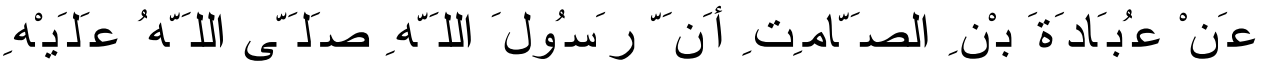

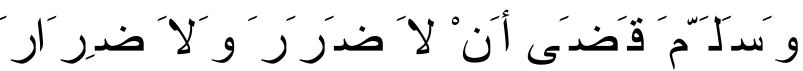

Artinya: Tidak ada bahaya terhadap diri sendiri dan terhadap orang lain (HR. Ibnu Mâjah, Ahmad, dan Mâlik). ${ }^{16}$

e. Larangan perbuatan memabukkan dan melemahkan sebagaimana disebutkan dalam hadis:

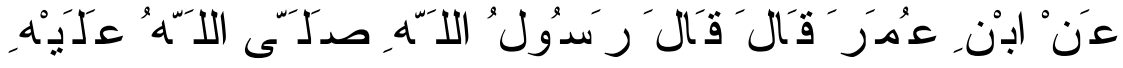

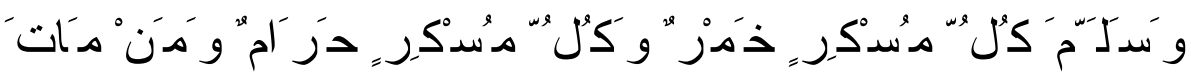

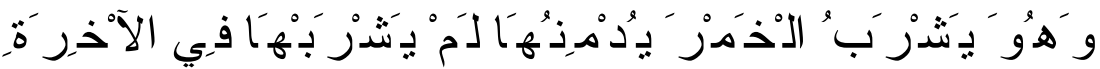

${ }^{16}$ Ahmad Ibnu Hambal, Ed. Syu'aib al- Arna'uth (Kairo: Mu'assasah al- Risalah) Cet. 2 Vol, h. 55, No. 2865. 
Artinya: dari Ibnu Umar ia berkata, "Rasulullah Saw bersabda: "Setiap sesuatu yang memabukkan adalah khamer, dan setiap yang memabukkan adalah haram. Barangsiapa meninggal dalam keadaan minum khamer dan menyukainya maka ia tidak akan meminumnya pada Hari Kiamat." (HR Ahmad dan Abû Dâud). ${ }^{17}$

f. Agama Islam (syariah) mempunyai tujuan (maqâsid asy-syarî'ah) untuk mewujudkan kemaslahatan hidup manusia. Perwujudan tujuan tersebut dicapai melalui perlindungan terhadap agama (hifd ad-dîn), perlindungan terhadpa jiwa/raga (an-nafs), perlindungan terhadap akal (al-'aql), perlindungan terhadap keluarga (an-nasl), dan perlindungan terhadap harta (al-mâl). Perlindungan terhadap agama dilakukan dengan peningkatan ketakwaan melalui pembinaan hubungan vertikal kepada Allah SWT dan hubungan horizontal kepada sesama dan kepada alam lingkungan dengan mematuhi berbagai norma dan petunjuk syariah tentang bagaimana berbuat baik (ihsân) terhadap Allah, manusia dan alam lingkungannya.

Perlindungan terhadap jiwa/raga diwujudkan melalui upaya mempertahankan suatu standar hidup yang sehat secara jasmani dan rohani serta menghindarkan semua faktor yang dapat membahayakan dan merusak manusia secara fisik dan psikis, termasuk menghindari perbuatan yang berakibat bunuh diri walaupun secara perlahan dan perbuatan menjatuhkan diri kepada kebinasaan yang dilarang di dalam al-Quran. ${ }^{18}$

Perlindungan terhadap akal dilakukan dengan upaya antara lain membangun manusia yang cerdas termasuk mengupayakan pendidikan yang terbaik dan menghindari segala hal yang bertentangan dengan upaya pencerdasan manusia. Perlindungan terhadap keluarga diwujudkan antara lain melalui upaya penciptaan suasana hidup keluarga yang sakinah dan penciptaan kehidupan yang sehat termasuk dan terutama bagi anak-anak yang merupakan tunas bangsa dan umat. Perlindungan terhadap harta diwujudkan antara lain melalui pemeliharaan dan pengembangan harta kekayaan materiil yang penting dalam rangka

${ }^{17}$ Abu Daud, Sunan Abu Daud, hadis nomor 3194.

18 Fathurrahman Djamil, Metode Ijtihad Majlis Tarjih Muhammadiyah, Cet. Ke-1, (Jakarta: Logos, 1995), h. 89. 
menunjang kehidupan ekonomi yang sejahtera dan oleh karena itu dilarang berbuat mubazir dan menghamburkan harta untuk hal-hal yang tidak berguna dan bahkan merusak diri manusia sendiri.

\section{Tahqîq al-Man' $\hat{\imath}$}

a. Penggunaan untuk konsumsi dalam bentuk rokok merupakan $98 \%$ dari pemanfaatan produk tembakau, dan hanya $2 \%$ untk penggunaan lainnya. ${ }^{19}$

b. Rokok ditengarai sebagai produk berbahaya dan adiktif serta mengandung 4000 zak kimia, di mana 69 di antaranya adalah karsinogenik (pencetus kanker). Beberapa zat berbahaya di dalam rokok tersebut di antaranya tar, sianida, arsen, formalin, karbonmonoksida, dan nitrosamin. Kalangan medis dan para akademisi telah menyepakati bahwa konsumsi tembakaku adalah salah satu penyebab kematian yang harus segera ditanggulangi.

c. Kematian balita di lingkungan orang tua merokok lebih tinggi dibandingkan dengan orang tua tidak merokok baik di perkotaan maupun di pedesaan. Kematian balita dengan ayah merokok di perkotaan mencapai $8,1 \%$ dan di pedesaan mencapai $10,9 \%$. Sementara kematian balita dengan ayah tidak merokok di perkotaan $6,6 \%$ dan di pedesaan 7,6\%. Resiko kematian populasi balita dari keluarga perokok berkisar antara 14\% di perkotaan dan 24\% di pedesaan. Dengan kata lain, 1 dari 5 kematian balita terkait dengan perilaku merokok orang tua. Dari angka kematian balita 162 ribu per tahun (Unicef 2000), maka 32.400 kematian dikontribusi oleh perilaku merokok orang tua. ${ }^{20}$

d. Adalah suatu fakta bahwa keluarga termiskin justru mempunyai prevelensi merokok lebih tinggi daripada kelompok pendapatan terkaya. Angkaangka SUSESAS 2006 mencatat bahwa pengeluaran keluarga termiskin untuk membeli rokok mencapai 11,9\%, sementara keluarga terkaya pengeluaran rokoknya hanya $6,8 \%$. Pengeluaran keluarga termiskin untuk rokok sebesar $11,9 \%$ itu menempati urutan kedua setelah pengeluaran

19 Departemen Kesehatan, Fakta Tembakau Indonesia: Data Empiris untuk Strategi Nasaional Penanggulangan Masalah Tembakau, 2004.

${ }^{20}$ Departemen Kesehatan, Fakta Tembakau Indonesia: Data Empiris untuk Strategi Nasaional Penanggulangan Masalah Tembakau, 2004

Vol. 4 No. 1 Tahun 2017 
untuk beras. Fakta ini memperlihatkan bahwa rokok pada keluarga miskin perokok menggeser kebutuhan makanan bergizi esensial bagi pertumbuhan balita. Ini artinya balita harus memikul resiko kurang gizi demi menyisihkan biaya untuk pembelian rokok yang beracun dan penyebab banyak penyakit mematikan itu. Ini jelas bertentangan dengan perlindungan keluarga dan perlindungan akal (kecerdasan) dalam maqâsid asy-syari'ah yang menghendaki pemeliharaan dan peningkatan kesehatan serta pengembangan kecerdasan melalui makanan bergizi. ${ }^{21}$

e. Pemaparan dalam halaqah Tarjih tentang Fikih Pengendalian Tembakau hari Ahad 21 Rabiul Awal 1431 H/07 Maret 2010 M, mengungkapkan bahwa Indonesia belum menandatangani dan meratifikasi Framework Convention on Tobacco Control (FCTC) sehingga belum ada dasar yang kuat untuk melakukan upaya pengendalian dampak buruk tembakau bagi kesehatan masyarakat. Selain itu terungkap pula bahwa cukai tembakau di Indonesia masih rendah dibandingkan beberapa negara lain sehingga harga rokok di Indonesia sangat murah yang akibatnya mudah dijangkau keluarga miskin dan bahkan bagi anak-anak sehingga prevalensi merokok tetap tinggi. Selain itu iklan rokok juga ikut merangsang hasrat mengkonsumsi zat berbahaya ini. ${ }^{22}$

\section{Fatwa Nahdatul Ulama (NU) Tentang Hukum Rokok}

NU sebagai salah satu ormas yang memiliki pengikut besar di Indonesia juga memiliki ketentuan-ketentuan yang harus diikuti oleh seluruh masyarakatnya. NU juga menerbitkan hukum-hukum atas suatu permasalahan yang dirasa belum memiliki hukum, atau masalah-masalah yang baru dan dipertanyakan hukumnya lewat sebuah lembaga yang bernama lajnah Bahtsul Masail. Dalam menentukan suatu hukum NU mengambil landasan Al-Qur'an, sunnah, ijma' dan juga pada kitab-kitab ulama' salaf. Begitu juga dalam penentuan hukum rokok, NU juga menggunakan kitab-kitab fiqih yang dapat

${ }^{21}$ Fatwa Majelis Tarjih dan Tajdid Muhammadiyah, No. 6/ SM/ MTT/ III/ 2010.
${ }^{22}$ Fatwa Majelis Tarjih dan Tajdid Muhammadiyah. 
diqiyaskan dengan hukum rokok itu sendiri, karena rokok tersebut merupakan suatu masalah yang dinilai baru dalam dunia Islam.

Rokok merupakan suatu hal yang baru yang belum memiliki hukum secara pasti. Berkaitan dengan hukum merokok, NU tidak mengeluarkan edaran secara resmi seperti Muhammadiyah. Namun, masalah ini disinggung dalam muktamar NU ke-2 yang terangkum dalam Ahkamul Fuqaha (kumpulan muktamar NU). ${ }^{23}$

Dalam hal hukum makruh yang dikenakan pada rokok tidak serta merta harus dihukumi makruh yang mendekati keharaman, karena ada berbagai pertimbangan-pertimbangan yang dijadikan landasan untuk mengimbangi hukum makruh tersebut, sehingga kemakruhannya tidak mendekati pada haram melainkan mendekati pada kebolehan atau nama lainnya adalah makruh tanzih.

Sesorang tidak diperbolehkan taqlid tanpa mengetahui landasan yang digunakan ketika dia melakukan sesuatu yang berkaitan dengan hukum. Meskipun didalamnya selalu ada madharatnya dan tidak sepenuhnya mengandung manfaat, akan tetapi banyak dikalangan ulama yang mengambil manfaat dari rokok meskipun jika dilihat itu merupakan sesuatu yang sederhana. jika suatu yang telah memiliki hukum, maka jangan sampai di otak-atik lagi hukumnya karena merupakan suatu hal yang sudah pasti. Akan tetapi jika rokok merupakan suatu hal yang belum memiliki hukum, maka diijtihadkan hukumnya sesuai dengan ketentuan-ketentuan ijtihad yang ada.

Bahtsul Masail Nadhlatul Ulama dalam menetapkan hukum menggunakan beberapa metode. Pertama, metode Qauli, metode ini adalah suatu cara istinbâth hukum yang digunakan oleh ulama NU dalam kerja bahtsul masail dengan mempelajari masalah yang dihadapi kemudian mencari jawabannya pada kitabkitab fiqih dari mahzab empat dengan mengacu dan merujuk secara langsung pada bunyi teksnya.

Keputusan bahtsul masail di lingkungan NU dibuat dalam kerangka bermahzab kepada salah satu mahzab empat yang disepakati dan mengutamakan bermahzab secara qauli. Oleh karena itu, prosedur penjawaban masalah disusun

${ }^{23}$ Lajnah Ta'lif wan Nasyr, Solusi Problematika Aktual Hukum Islam, (Surabaya: Khalista, tt). hlm.28 
dalam urutan sebagai berikut: Dalam kasus ketika jawaban bisa dicukupi oleh ibarat kitab dan disana hanya terdapat satu qaul/wajh, maka dipakailah qaul/wajh sebagaimana dalam urutan tersebut. Dalam kasus ketika jawaban bisa dicukupi oleh ibarat kitab dan disana terdapat lebih dari satu qaul/wajh, maka dilakukan taqrir jamai untuk memilih salah satu qaul/wajh. ${ }^{24}$

Prosedur pemilihan qaul/wajh adalah ketika dalam satu masalah dijumpai beberapa qaul/wajh dilakukan dengan memilih salah satu pendapat dengan ketentuan bahwa pendapat yang disepakati oleh As-Syakhani (imam Nawawi dan Ar-Rafii), pendapat yang dipegangi oleh An-Nawawi saja, pendapat yang dipengangi oleh Ar-Rafii saja, Pendapat yang didukung oleh mayoritas ulama, Pendapat ulama yang terpandai, Pendapat ulama yang paling wara. ${ }^{25}$

Kedua, Metode Ilhaqi apabila metode qauli tidak dapat dilaksanakan karena tidak ditemukan jawaban tekstual dari kitab mu'tabar, maka yang dilakukan adalah apa yang disebut dengan ilhaq al-masail bi nazariha yakni menyamakan hukum suatu kasus/masalah yang belum dijawab oleh kitab (belum ada ketetapan hukumnya), atau menyamakan dengan pendapat yang sudah jadi. Sama dengan metode qauli metode ini secara operasional juga telah diterapkan sejak lama oleh para ulama NU dalam menjawab permasalahan keagamaan yang diajukan oleh umat Islam khususnya warga Nahdiyin, walaupun baru secara implisit dan tanpa nama sebagai metode ilhaqi.

Untuk menyelesaikan masalah yang tidak ada qaul/wajh sama sekali maka dilakukan dengan ilhaq al-masail bi nazariha secara jamai oleh para ahlinya. Sedangkan prosedur ilhaq adalah dengan memperhatikan ketentuan bahwa mulhaq bih (sesuatu yang belum ada ketentuan hukumnya), mulhaq 'alayhi, (sesuatu yang sudah ada ketentuan hukumnya), wajh al-ilhaq (faktor keserupaan antara mulhaq bih dan mulhaq 'alayhi), oleh para mulhiq yang ahli. Metode penjawaban permasalahan seperti ini kemudian disebut sebagai metode ilhaqi.

Dalam prakteknya menggunakan prosedur dan persyaratan mirip qiyas. Oleh karenanya, dapat juga dinamakan metode qiyas versi NU. Ada perbedaan

\footnotetext{
${ }^{24}$ Lajnah Ta'lif wan Nasyr, Solusi Problematika,...hlm. 84-89

25 Muhtadi Anshor, Bath Al-Masail Nahdlatul Ulama Melacak Dinamika Pemikiran Mahzab Kaum Tradisionalis, (Yogyakarta, 2012, tt.), hlm. 84-89.
}

Vol. 4 No. 1 Tahun 2017 
antara qiyas dan ilhaq. Yaitu kalau qiyas adalah menyamakan hukum sesuatu yang belum ada ketetapannya dengan sesuatu yang sudah ada kepastian hukumnya berdasarkan nash Al-Quran atau As-Sunnah. Sedangkan ilhaq adalah menyamakan hukum sesuatu yang belum ada ketetapannya dengan sesuatu yang sudah ada kepastian hukumnya berdasarkan teks suatu kitab mu'tabar. ${ }^{26}$

Apabila masalah atau pertanyaan tidak terdapat jawabannya sama sekali dalam kitab-kitab standard baik qauli maupun wajh, dan tidak memungkinkan untuk melakukan ilhaq, maka langkah yang ditempuh adalah istinbâth secara kolektif dengan prosedur bermahzab secara manhaji oleh para ahlinya.

Istinbâth hukum merupakan prosedur yang terakhir, yaitu ia dapat dilakukan apabila suatu masalah atau pertanyaan tidak terdapat jawabannya dalam kitab-kitab standar, sehingga tidak ada peluang untuk melakukan pemilihan pendapat dan tidak memungkinkan ulama untuk melakukan ilhaq karena tidak ada mulhaq bih dan wajh al-ilhaq. Istinbâth dilakukan secara jamai dengan memperaktekkan dan mengaplikasikan kaidah ushul dan kaidah fikih. ${ }^{27}$

Ketiga, Metode Manhaji. Metode manhaji adalah suatu cara menyelesaikan masalah keagamaan yang ditempuh dalam bahtsul masail dengan mengikuti jalan pikiran dan kaidah-kaidah penetapan hukum yang telah disusun imam mahzab. Sebagaimana metode qauli dan il-haqi, sebenarnya metode manhaji ini juga sudah diterapkan oleh para ulama NU terdahulu walaupun tidak dengan istilah manhaji dan tidak pula diresmikan melalui sebuah keputusan.

Jawaban terhadap permasalahan yang dikaji dalam bahtsul masail yang tidak mencantumkan dalil dari suatu kitab ataupun memberikan suatu argumentasi detail, setelah tidak dapat dirujukan kepada teks suatu kitab mu'tabar maka dilakukan metode manhaji dengan mendasarkan jawaban mula-mula pada Al-Quran, setelah tidak ditemukan jawabannya dalam Al-Quran lalu dalam hadis dan begitu seterusnya dan akhirnya sampailah pada jawaban dari kaidah fiqih.

Dua cara istinbâth hukum yang dilakukan oleh Nahdlatul Ulama (NU). Melalui pendekatan fiqhiyyah dan pendekatan ushuliyyah. Kaidah fiqhiyyah lebih

\footnotetext{
${ }^{26}$ Muhtadi Anshor, Bath Al-Masail Nahdlatul Ulama,...hlm. 84-89.

${ }^{27}$ Muhtadi Anshor, Bath Al-Masail Nahdlatul Ulama,... hlm. 179-181.
} 
didahulukan dari kaidah ushuliyyah yang secara umum telah disepakati oleh para ulama sebagai thariqah istinbâth hukum, di samping itu juga mengingat eksistensi kaidah fiqhiyyah yang sangat penting dalam studi fiqih.

Landasan atas makruhnya merokok di dasarkan pada kaidah fikih "segala sesuatu pada asalnya adalah mubah”. Di tambah juga dengan qaul 'Abdur Rahman ibn Muhammad ibn Husain ibn 'Umar Ba'alawiy yang tertera di dalam Bughyatul Mustarsyidin :

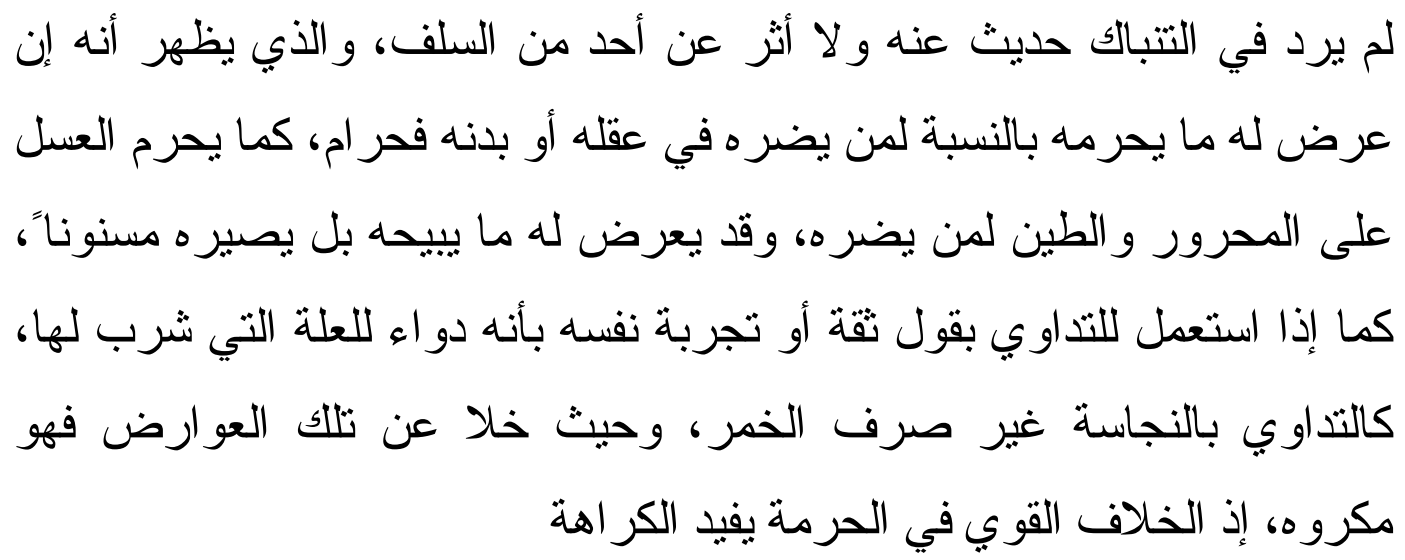

Artinya: Tidak ada hadits mengenai tembakau dan tidak ada atsar (ucapan dan tindakan) dari seorang pun di antara para shahabat Nabi SAW. Jelasnya, jika terdapat unsur-unsur yang membawa mudarat bagi seseorang pada akal atau badannya, maka hukumnya adalah haram sebagaimana madu itu haram bagi orang yang sedang sakit demam, dan lumpur itu haram bila membawa mudarat bagi seseorang. Namun kadangkala terdapat unsur-unsur yang mubah tetapi berubah menjadi sunnah sebagaimana bila sesuatu yang mubah itu dimaksudkan untuk pengobatan berdasarkan keterangan terpercaya atau pengalaman dirinya bahwa sesuatu itu dapat menjadi obat untuk penyakit yang diderita sebagaimana berobat dengan benda najis selain khamr. Sekiranya terbebas dari unsur-unsur haram dan mubah, maka hukumnya makruh karena bila terdapat unsur-unsur yang bertolak belakang dengan unsurunsur haram itu dapat difahami makruh hukumnya. ${ }^{28}$

Demikian pula apa yang telah dijelaskan oleh Prof Dr Wahbah AzZuhailiy di dalam Al-Fiqh al-Islamiy wa Adillatuh dengan sepotong teks, sebagai berikut:

28 'Abdur Rahman ibn Muhammad ibn Husain ibn 'Umar Ba'alawiy, Bughyatul Mustarsyidin (Beirut: Dar Al-Fikri, tt.), h. 260. 


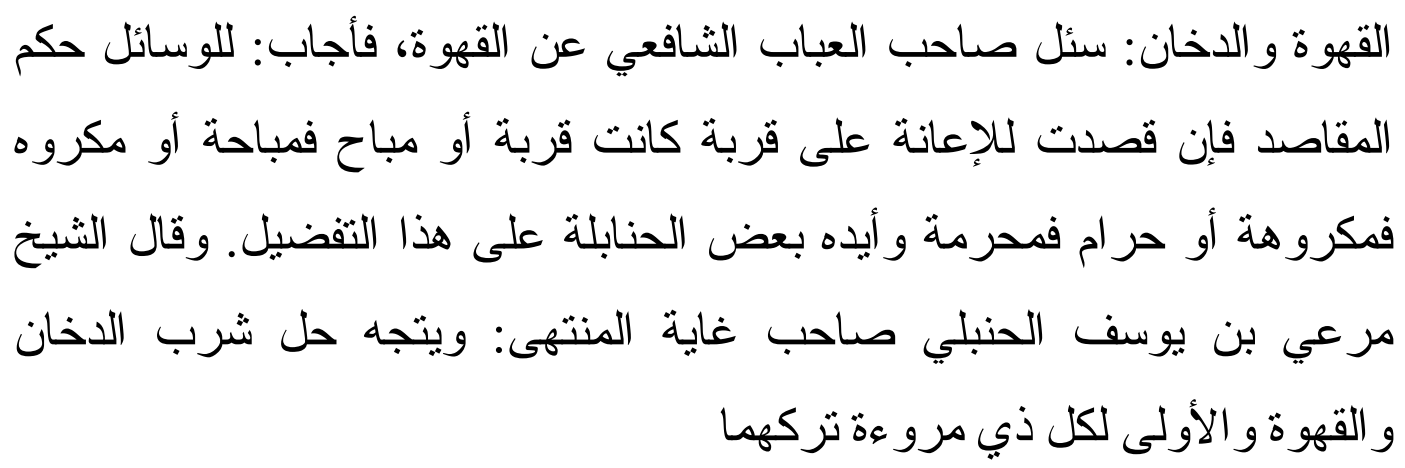

Artinya: Masalah kopi dan rokok; penyusun kitab Al-'Ubab dari madzhab AsySyafi'i ditanya mengenai kopi, lalu ia menjawab: (Kopi itu sarana) hukum, setiap sarana itu sesuai dengan tujuannnya. Jika sarana itu dimaksudkan untuk ibadah maka menjadi ibadah, untuk yang mubah maka menjadi mubah, untuk yang makruh maka menjadi makruh, atau haram maka menjadi haram. Hal ini dikuatkan oleh sebagian ulama' dari madzhab Hanbaliy terkait penetapan tingkatan hukum ini. Syaikh Mar'i ibn Yusuf dari madzhab Hanbaliy, penyusun kitab Ghayah al-Muntaha mengatakan: Jawaban tersebut mengarah pada rokok dan kopi itu hukumnya mubah, tetapi bagi orang yang santun lebih utama meninggalkan keduanya. ${ }^{29}$

Dengan demikian, ada sebagian besar ulama' berpandangan, bahwa merokok itu mubah atau makruh. Mereka lebih bertendensi pada bukti, bahwa merokok tidak membawa mudarat, atau membawa mudarat tetapi relatif kecil. Barangkali dalam gambaran kita sekarang, bahwa kemudaratan merokok dapat pula dinyaakan tidak lebih besar dari kemudaratan durian yang jelas berkadar kolesterol tinggi. Betapa tidak, sepuluh tahun lebih seseorang merokok dalam setiap hari merokok belum tentu menderita penyakit akibat merokok. Sedangkan selama tiga bulan saja seseorang dalam setiap hari makan durian, kemungkinan besar dia akan terjangkit penyakit berat.

\section{Penutup}

Secara garis besar fatwa Muhammadiyah berangkat dari asumsi bahwa kemudharatan yang ditimbulkan rokok lebih besar daripada kemanfaataannya, sementara yang melatarbelakangi NU memberikan hukum rokok makruh adalah tidak adanya satu dalil atau nash, maupun hadist yang secara langsung melarang

${ }^{29}$ Wahbah Az-Zuhailiy, Al-Fiqh al-Islamiy wa Adillatuh, Cet. III, Jilid 6, (Beirut: Dar alFikr, 2000), h. 166-167. 
dan mengharamkan rokok, dan tidak ada illat yang jelas dan kuat, sehingga NU memberikan hukum makruh.

NU dan Muhammadiyah sepakat dalam tataran takhrijul manath ( تخريج (المناط yakni bahwa setiap yang membahayakan haram di konsumsi. Namun keduanya berbeda dalam tataran tahqiqul manath (تحقيق المناط). Menurut Muhammadiyah rokok membahayakan sementara menurut NU rokok mempunyai potensi untuk membahayakan.

\section{DAFTAR PUSTAKA}

Asjmuni Abdurrahman, Manhaj Tarjih Muhammadiyah: Metodologi dan Aplikasi, Cetakan III, (Yogyakarta: Pustaka Pelajar, 2004)

Asy-Syatibi, Abu Ishaq. Al-I'tisham.(Beirut: Dar al Ma'rifah,2000)

Alal al Fasi, Maqasid al-shariah al-Islamiyah wa Makarimuha. (Beirut: Maktabah Al Wahdah al Arabiyah,1963)

Auda, Jasser. Maqasid syariah as philoshopy of Islamic Law; a system Approach. (London: International Institut of Islamic Thought, 2007) Maqasid syariah as philoshopy of Islamic Law; a system Approach,terj.Ali Abd el-Mun'im, Filsafat Makasid Syariah pendekatan system.Medan: La tansa press, 2014

Alal al Fasi, Maqasid al-shariah al-Islamiyah wa Makarimuha. (Beirut: Maktabah Al Wahdah al Arabiyah,1963)

Basyir, Abu Umar, Mengapa Ragu tinggalkan Rokok, Jakart, (Pustaka At-Tazkia, 2006)

Fathurrahman Djamil, Metode Ijtihad Majlis Tarjih Muhammadiyah, Cet. Ke-1, (Jakarta: Logos, 1995)

Jaih Mubarok, Metodologi Ijtihad Hukum Islam, (Yogyakarta: UII Press, 2002)

Muhtadi Anshor, Bath Al-Masail Nahdlatul Ulama Melacak Dinamika Pemikiran Mahzab Kaum Tradisionalis, (Yogyakarta, 2012, tt.)

Muzadi, Hasyim, Fatwa Nu: Rokok Makruh, Suara Merdeka, Semarang edisi 11Maret 2010

Syaikh Ihsan Jampes, Kitab Kopi Dan Rokok, Untuk Para Pecandu Rokok dan Penikmat Kopi”, (Yogyakarta, Pustaka Pesantren, 2009) 
AL-QADHA Jurnal Hukum Islam Dan Perundang-undangan

Wahab, Abdul, Kaidah-Kaidah Hukum Islam (Ilmu Ushulul Figh) Alih Bahasa Noer Iskandar Al Barsani Dan Moch Tolkhah, Jakarta, Raja Grafindo Persada, 1993

Wahbah Az-Zuhailiy, Al-Fiqh al-Islamiy wa Adillatuh, Cet. III, Jilid 6, (Beirut: Dar al-Fikr, 2000)

Zahro, Ahmad, Lajnah Bahtsul Masa'il 1926-1999, Tradisi Intelektual NU, (Yogyakarta, LkiS, 2004) 